\title{
Trajectories of Late Permian - Jurassic radiolarian extinction rates: no evidence for an end-Triassic mass extinction
}

\author{
Wolfgang Kiessling*,1,2 and Taniel Danelian ${ }^{2}$ \\ ${ }^{1}$ Museum für Naturkunde Berlin, Invalidenstraße 43, 10115 Berlin, Germany. E-mail: wolfgang.kiessling@mfn-berlin.de \\ ${ }^{2}$ Laboratoire Géosystèmes (FRE 3298), Université Lille 1, UFR des Sciences de la Terre - bâtiment SN, 59655 Villeneuve d'Ascq cedex, France
}

\begin{abstract}
Received 4 August 2010

Accepted 25 August 2010

Published 21 February 2011

\section{Key Words}

Radiolarians

ocean acidification

Triassic

sampling standardization

The hypothesis that ocean acidification was a proximate trigger of the marine endTriassic mass extinction rests on the assumption that taxa that strongly invest in the secretion of calcium-carbonate skeletons were significantly more affected by the crisis than other taxa. An argument against this hypothesis is the great extinction toll of radiolarians that has been reported from work on local sections. Radiolarians have siliceous tests and thus should be less affected by ocean acidification. We compiled taxonomically vetted occurrences of late Permian and Mesozoic radiolarians and analyzed extinction dynamics of radiolarian genera. Although extinction rates were high at the end of the Triassic, there is no evidence for a mass extinction in radiolarians but rather significantly higher background extinction in the Triassic than in the Jurassic. Although the causes for this decline in background extinction levels remain unclear, the lack of a major evolutionary response to the end-Triassic event, gives support for the hypothesis that ocean acidification was involved in the dramatic extinctions of many calcifying taxa.
\end{abstract}

\section{Introduction}

The evolutionary response of radiolarians to global environmental perturbations is poorly explored (Racki 1999). Yet the fact that polycystine radiolarians secrete siliceous skeletons along with their great diversity, abundance, and long geologic record offers unique opportunities to assess the proximate causes of ancient mass extinction episodes. This is especially evident at the end-Triassic mass extinction when a major extinction of marine calcium-carbonate-secreting organisms occurred (Kiessling et al. 2007) and an ocean acidification event was seen as its dominant trigger (Hautmann 2004; Hautmann et al. 2008). If, as suggested by Hautmann et al. (2008), radiolarians had very minor extinctions across the Triassic-Jurassic boundary, ocean acidification would be a more plausible extinction mechanism than if extinctions in radiolarians were as severe as in other groups.

That radiolarians suffered considerable extinctions has long been suggested, based on detailed work on sections in British Columbia and Japan (Hori 1992;
Carter 1993, 1994; Carter et al. 1998; Carter \& Hori 2005). However, the statement that nearly 20 genera and over 130 species of radiolarians went extinct (Carter \& Hori 2005) needs to be put in context, not only in the context of standing diversity, but also in relation to long-term trajectories of extinction rates. Neither qualitative observations on reductions in test size and architectural complexity (Longridge et al. 2007) nor higher estimates on genus extinction (27 according to O'Dogherty et al. 2010) suffice to qualify this statement.

Here we explore a large dataset of Late Permian and Mesozoic radiolarian occurrences to assess the magnitude of the end-Triassic extinction and compare it with extinctions at other stage boundaries. Complete faunal lists from 200 publications have been entered in the $\mathrm{Pa}$ leobiology Database (http://paleodb.org). The dataset was taxonomically vetted based on De Wever et al. (2001), O'Dogherty et al. (2009a, 2009b), and personal expertise. Data were downloaded on August 3, 2010. Taxonomic occurrences for which the genus assignment was in any way doubtful were excluded from the down-

* Corresponding author 
load. Raw and sampling-standardized biodiversity dynamics were assessed at the level of geologic stages and computed with scripts developed in the R programming environment. Occurrences that could not be assigned precisely to a particular stage were randomly assigned to one if the uncertainty was between two neighboring stages. Otherwise they were excluded from the analysis. The final file comprised 27670 occurrences of 564 radiolarian genera. Because extinction rates $(E)$ were based on exponential decay functions (Foote 2000), they are not bound by one as are proportional extinction rates:

$E=-\ln \left[N_{\mathrm{bt}} /\left(N_{\mathrm{bt}}+N_{\mathrm{bL}}\right)\right]$

where $N_{\mathrm{bt}}$ is the number of genera crossing both the bottom and top of an interval and $N_{\mathrm{bL}}$ is the number of genera crossing the bottom but not the top of an interval.

\section{Results}

\section{Raw patterns}

Raw data at the genus level suggest that only 12 genera are last recorded in the Rhaetian stage. With 57 surviving genera we achieve an extinction percentage of $17 \%$, which can hardly be classified as a mass extinction. However, a number of survivors are recorded from only one region (British Columbia) and only in the basal Hettangian (Longridge et al. 2007) (Tab. 1). Although the samples containing these survivors show no evidence of reworking, we excluded those samples from all further analyses and treated the short-term survivors as victims. This suggests 20 extinct genera and an extinction percentage of $29 \%$, which is still not particularly high but could represent a mass extinction if background extinction rates were low. To test this, we need to look at the long-term trajectory of extinction rates. This trajectory calculated for the observed stratigraphic ranges of genera, suggests that extinction rates were higher than typical Jurassic values but in the same range as any Triassic stage boundary except the Norian (Fig. 1). Rhaetian extinction rates are considerably lower than Norian rates. Although the much longer duration of the Norian stage may provide more opportunity for extinction, we refrain from normalizing extinction rates by interval duration because it has been shown that extinctions tend to be pulsed at the end of stages rather than uniformly spread through stages (Foote 2005), such that there is no linear relationship between stage duration and extinction rate. That this also applies to radiolarians is suggested by the absence of a correlation between the duration of stages and extinction rates (Spearman rank-order correlation $R=0.08, p=0.74$ ).

The end-Permian mass extinction is high, but not extremely high, owing to the survival of several Permian genera into the earliest Triassic (Takemura et al. 2007). Their delayed extinction in southern high paleolatitudes causes the Induan extinction levels to be higher than in most other Triassic stages, except the Norian. The raw data thus suggest that there was no mass extinction of radiolarians across the Triassic-Jurassic boundary. Instead extinction rates were rising through most of the Triassic culminating in the Norian and declining into the Early Jurassic. The Sinemurian and Pliensbachian stages exhibit extinction rates in the same range as the Rhaetian but from the Toarcian onward extinction rates were extremely low.

It is conceivable that extinction toll was modest across the end-Triassic mass extinction but radiolarians responded ecologically by reduced population sizes. If this were the case, we would expect a pronounced La-

Table 1. Range extensions of genera thought to become extinct at the end of the Triassic by O'Dogherty et al. (2009a). Hettangian finds of Longridge et al. (2007) are short-term survivors and considered as victims of the end-Triassic extinctions in our analyses.

\begin{tabular}{|c|c|c|}
\hline Genus & Post-Triassic occurrences & Reference \\
\hline Betraccium & Sinemurian of the Philippines & Yeh \& Cheng (1998) \\
\hline Cantalum & Hettangian of British Columbia & Longridge et al. (2007) \\
\hline Deflandrecyrtium & Aalenian of Japan & Yao (1997). Questionable assignment \\
\hline Eptingium & Hettangian of British Columbia & Longridge et al. (2007) \\
\hline Globolaxtorum & Hettangian of British Columbia & Longridge et al. (2007) \\
\hline Icrioma & Hettangian of British Columbia & Longridge et al. (2007) \\
\hline Kungalaria & Hettangian of British Columbia & Longridge et al. (2007) \\
\hline Livarella & Sinemurian of the Philippines & Yeh \& Cheng (1998) \\
\hline Nabolella & Hettangian of British Columbia & Longridge et al. (2007) \\
\hline Plafkerium & Hettangian of British Columbia & Longridge et al. (2007) \\
\hline Praemesosaturnalis & $\begin{array}{l}\text { Sinemurian of the Philippines; Pliensbachian of Turkey } \\
\text { (as Pseudoheliodiscus) }\end{array}$ & Yeh \& Cheng (1998); De Wever (1981) \\
\hline Pseudohagiastrum & Hettangian of British Columbia & Longridge et al. (2007) \\
\hline Serilla & Hettangian of British Columbia & Longridge et al. (2007) \\
\hline
\end{tabular}




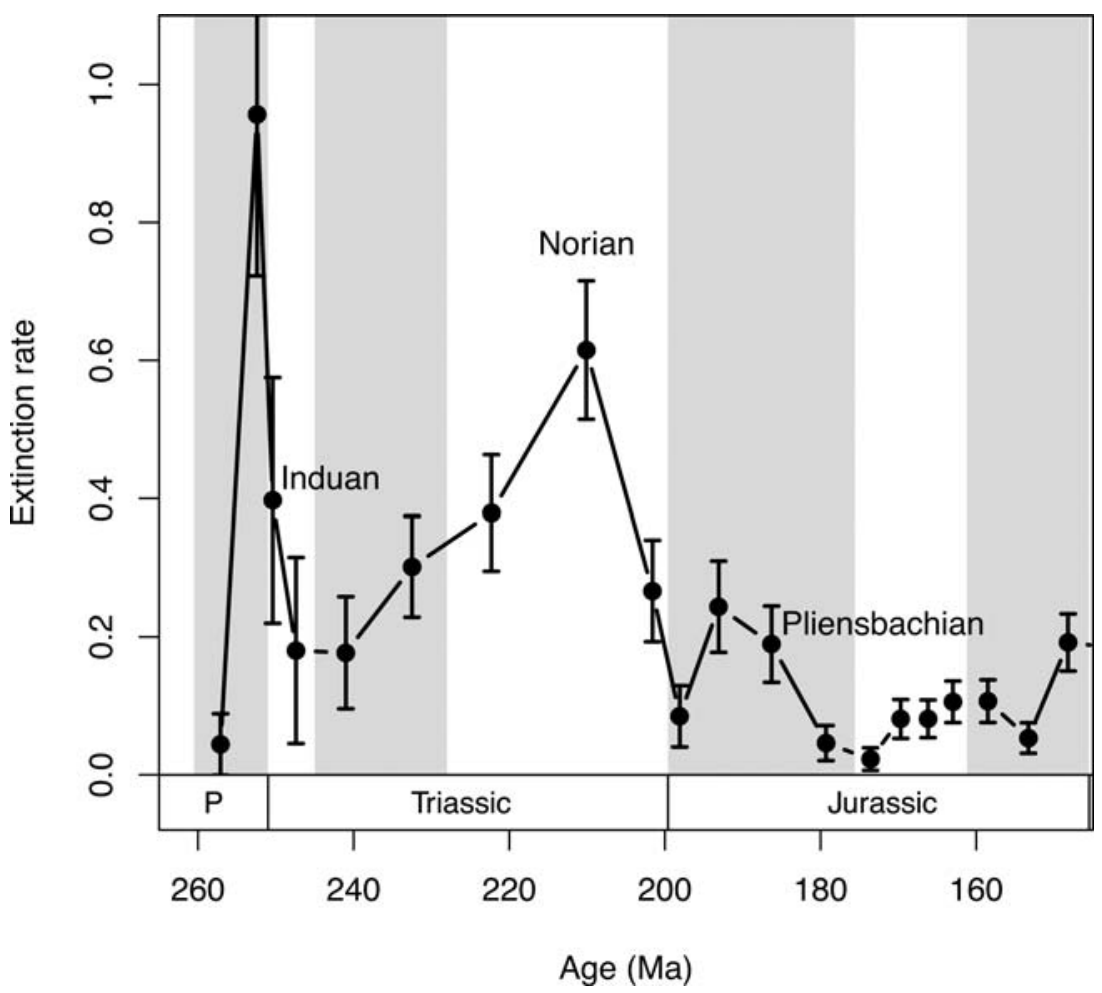

Figure 1. Raw pattern of radiolarian genus extinction rates from Late Permian to Late Jurassic times. Extinction rates are calculated after Foote (2000) but not normalized for stage durations. Error bars report on standard deviation in each direction of a bootstrap resampling of the stratigraphic ranges of genera with 1000 iterations. Geological epochs are shaded. zarus effect in the Hettangian stage (Wignall \& Benton 1999). To test this, we calculated the sampling completeness of genera in each stage by the ratio of sampled genera and sampling opportunities excluding the times of origination and extinction when a taxon has to be sampled. The result suggests that sampling completeness is best in the Late Permian, drops substantially in the Early Triassic, and is remarkably constant from Middle Triassic to the Late Jurassic (Fig. 2). A slight drop in sampling probability is observed in the Hettangian but this is not significant and much smaller than the drop observed in the Early Triassic. Therefore, a pronounced Lazarus effect cannot be seen in earliest Jurassic radiolarians.

Finally, we traced the proportional number of occurrences in radiolarian orders. These may provide additional insights into ecological changes. Because the Entactinaria dominate most Early Triassic assemblages

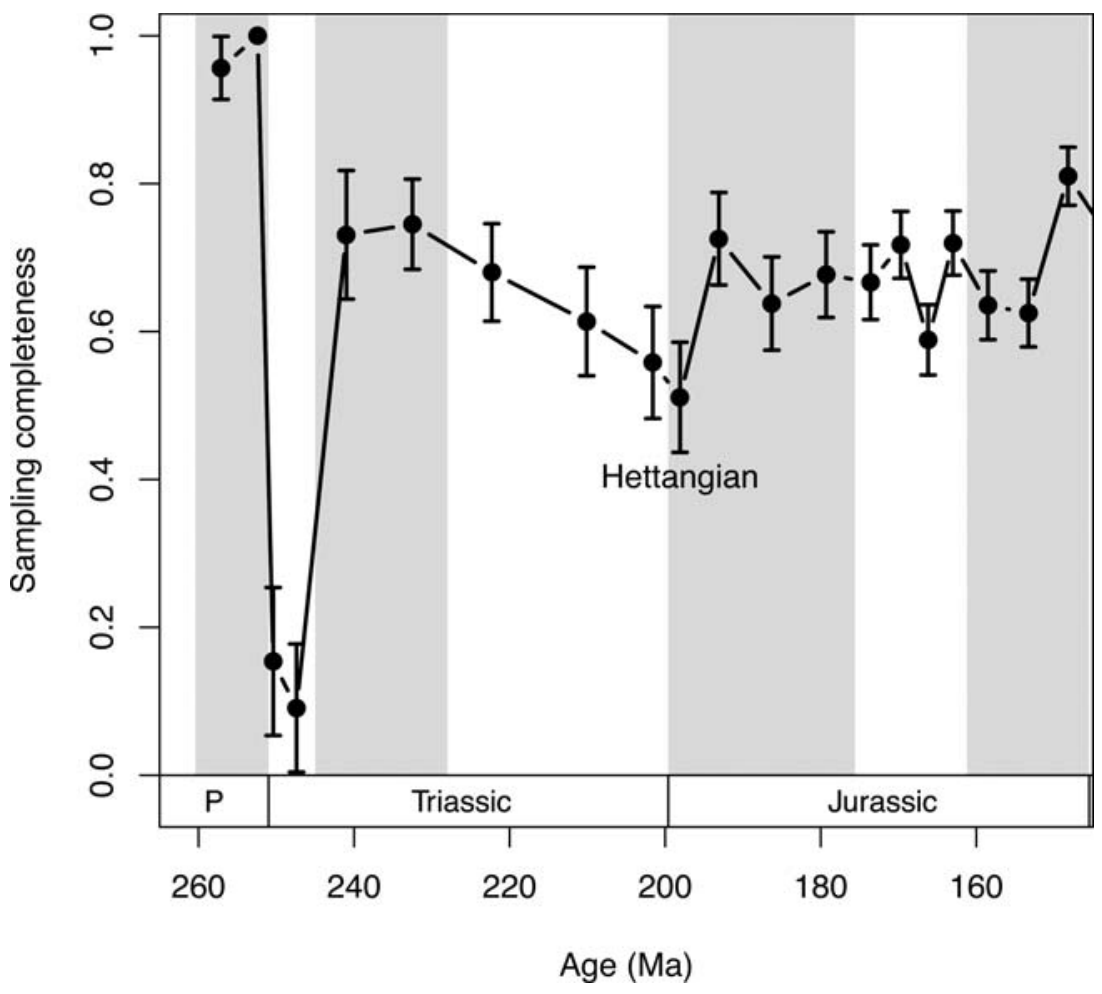

Figure 2. Sampling completeness of radiolarian genera per stage. Error bars denote binomial standard errors in each direction. In contrast to the Early Triassic and Carnian, there was no significant reduction of radiolarian preservation in the Hettangian suggesting that the decline of population sizes was modest or shorter than the duration of the stage. 


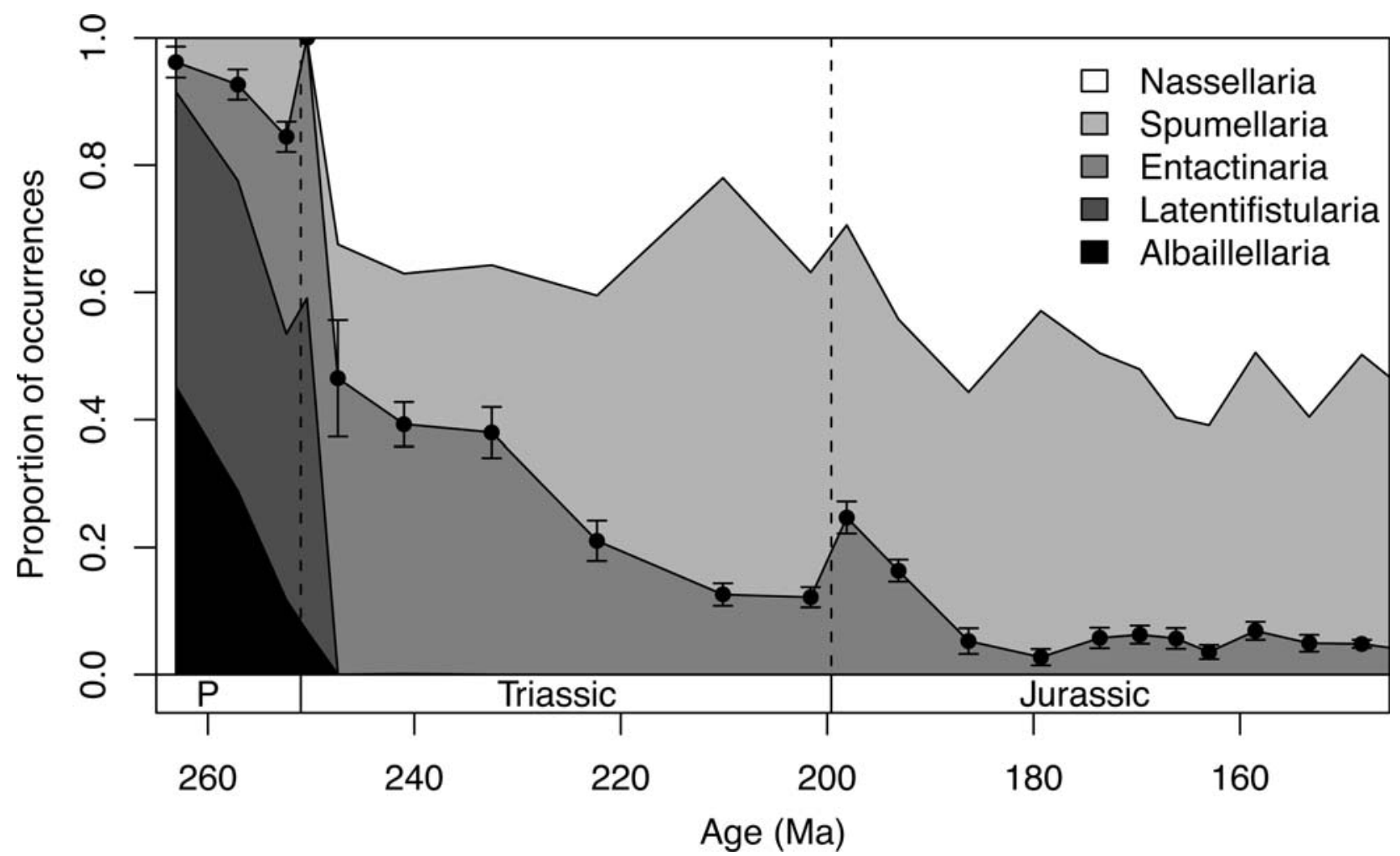

Figure 3. Proportional occurrence counts of five radiolarian orders per stage. The error bars on Entactinaria are two standard errors of the proportions in each direction. The long-term decline of this order was interrupted by small but significant spikes in the earliest Triassic and earliest Jurassic.

(De Wever et al. 2006; Takemura et al. 2007) their abundance may be indicative of environmental turmoil. The trends depicted in Figure 3 confirm previous depictions for the Early Triassic and suggest that the earliest Jurassic also saw a transient and minor rise of entactinarians. The level of our analysis cannot detect ecological responses on finer taxonomic levels and shorter time scales that have been reported from Canada and Japan (Carter \& Hori 2005). The moderate increase of entactinarians at the expense of nassellarians is the only indication of an ecological response to the end-Triassic events at this temporal resolution.

\section{Sampling-standardized patterns}

The results based on raw data could be biased by heterogeneous sampling. Heterogeneity of sampling may have some biological underpinning (e.g., there are few radiolarian faunas in the Early Triassic) but nevertheless needs to be considered for assessing biodiversity dynamics. We conducted by-list occurrences-weighted subsampling (OW: Alroy et al. 2001) to test if the raw extinction trajectories were substantially affected by sampling bias. To maintain a complete time series we combined occurrences in the Induan and Olenekian stages and first chose a small subsampling quota of 150 occurrences. We then raised the subsampling quota to 400 occurrences to be more inclusive on the fate of rare genera. This resulted in a loss of information on the earlier part of the time series but preserved the important Middle Triassic through Jurassic interval. The results confirm that no major extinction of radiolarians can be recognized across the Triassic-Jurassic boundary (Fig. 4). The early Triassic extinctions seem to have been as profound as the end-Permian mass extinction (Fig. 4A) suggesting that the drop of extinction rates seen in the raw data (Fig. 1) is due to sampling bias. Likewise the disappearance of the Norian extinction spike suggests that this is largely a sampling artifact in the raw data. That the Norian extinctions tend to become higher with an increasing subsampling quota (Fig. 4B) indicates that they dominantly affected genera that were already rare in the Norian. Importantly, both subsampling approaches confirm that the Rhaetian extinctions were the lowest in the Late Triassic and among the lowest in the entire Triassic. These results confirm that there is no evidence for a mass extinction of radiolarians at the end of the Triassic.

\section{Discussion}

\section{No mass extinction but a decline in background extinctions}

All results indicate that radiolarians did not show pronounced evolutionary or ecological responses to the environmental perturbations that caused the end-Triassic mass extinction. Although extinction rates were cer- 


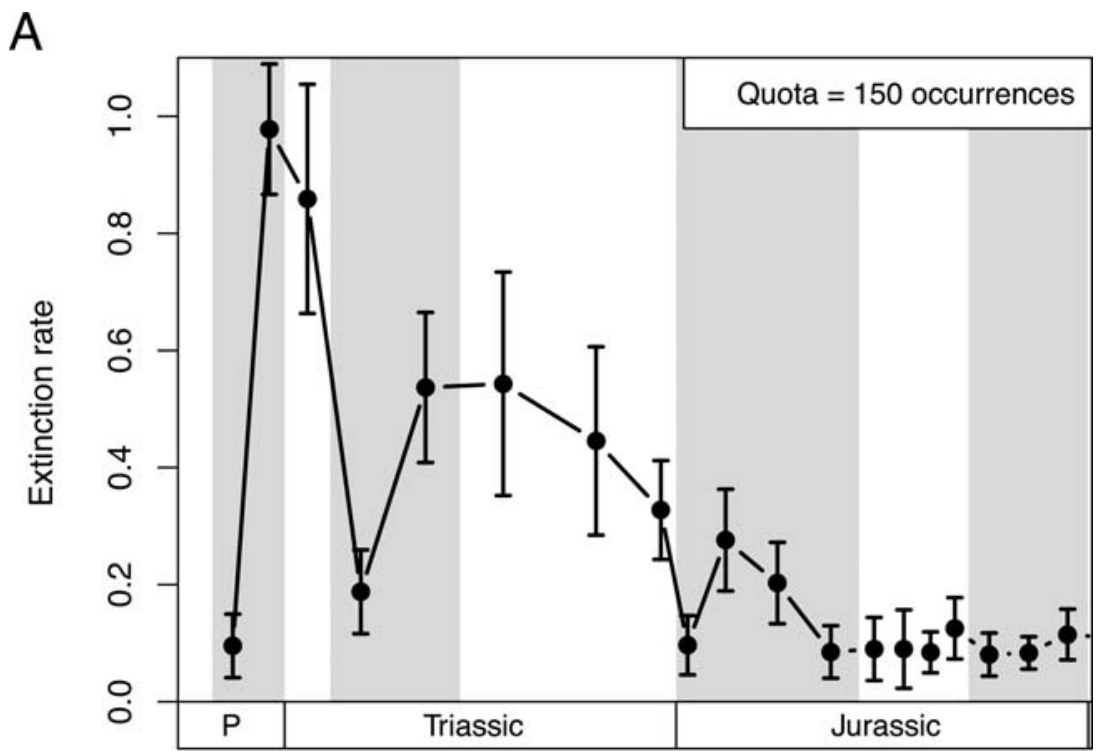

B

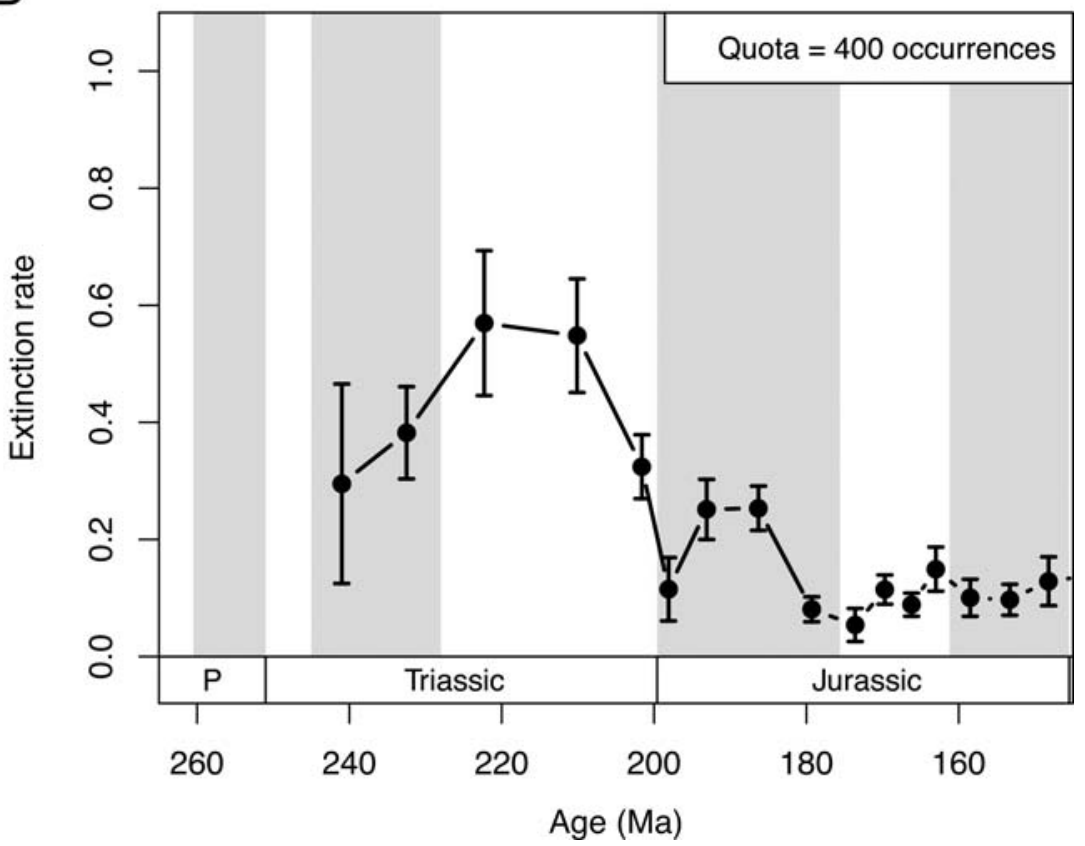

Figure 4. Subsampled extinction rates of radiolarian genera employing occurrences-weighted by list subsampling and 100 subsampling trials of (A) 150 occurrences and (B) 400 occurrences. Error bars denote one standard deviation in each direction. Only values within continuous time series are shown. Radiolarians crossed the Triassic-Jurassic boundary relatively unscathed. tainly higher than the $4.5 \%$ reported by Hautmann et al. (2008), which were based on Sepkoski's (2002) compendium on stratigraphic ranges of marine genera, they cannot be distinguished from Triassic background extinction levels. Somewhat higher extinction rates would be achieved, if the ranges given by O'Dogherty et al. (2009c, 2010) were taken at face value. However, several genera that are listed as having their last occurrence at the end of the Rhaetian are indeed described from younger intervals (Tab. 1) and some do not appear to be recorded in the Rhaetian. As indicated in the results section, the surviving genera from British Columbia (Tab. 1) were treated as victims in our analysis, because they were considered as short-term survivors from a major perturbation by Longridge et al. (2007). However, that extinction rates continued to be moderately high until the Pliensbachian suggests that Hettangian extinctions were just within the elevated back- ground rates continuing from the Triassic. Overall, there was a significant decline in background extinction levels from the Triassic $($ mean $=0.43)$ into the Jurassic (mean $=0.13$; one-tailed Wilcoxon rank sum test based on subsampling of 400 occurrences: $\mathrm{W}=55$, $p=0.0002$ ). So we may ask why the evolutionary turnover was so much higher in the Triassic than in the Jurassic. As this observation has also been made for marine benthic metazoans (Kiessling et al. 2007) there may be an environmental underpinning.

Environmental stress has been evoked to explain the commonness of twisted spines in Triassic radiolarians (De Wever et al. 2001, 2003). However, except for the Early Triassic (Galfetti et al. 2007) and the Carnian (Simms \& Ruffell 1989) there is little direct evidence for unusual environmental and climate change during the Triassic (Preto et al. 2010). And the Jurassic also saw substantial changes such as the Toarcian anoxic 
event (Hesselbo et al. 2000) and the Callovian-early Oxfordian cooling episode (Dromart et al. 2003). None of these events seems to have caused dramatic extinctions of radiolarian genera. Although the Pliensbachian extinction rates (immediately before the Toarcian) were slightly above the later Jurassic background, they are indistinguishable from Sinemurian extinction rates (Fig. 4B) such that the link to the Toarcian anoxia remains unclear.

The higher Triassic extinctions could also be due to the frequency of taxa with high intrinsic turnover rates such as the entactinarians. However, the differences in background rates are maintained when entactinarians are excluded and can also be seen in individual orders such as spumellarians. Therefore, the causes for the higher Triassic background extinctions remain unclear at this point.

\section{Causes of the end-Triassic mass extinction}

There is now ample evidence that the giant Central Atlantic Magmatic Province (CAMP) largely erupted in the latest Triassic over a geologically short interval of time (Marzoli et al. 1999, 2004; Cirilli et al. 2009). A causal link to the end-Triassic mass extinction has long been proposed but there is still dispute over the proximate trigger of the extinctions. A massive release of $\mathrm{CO}_{2}$ was certainly associated with the volcanic eruptions, which can be traced by a decrease of stomatal density of fossil leaves (McElwain et al. 1999) and carbon-isotopes of paleosoils (Beerling 2002). Global warming and ocean acidification should have been associated and might have been a trigger of the extinctions (Hautmann 2004; Hautmann et al. 2008; Kiessling \& Simpson 2010). On the other hand, global warming is probably insufficient to explain the relatively large vegetation shifts on land, which led van de Schootbrugge et al. (2009) to suggest that the volcanic release of $\mathrm{SO}_{2}$ and other pollutants might have played an additional if not outstanding role in the extinctions.

Whereas radiolarians cannot contribute to clarifying the effects of warming and pollutants, they should be less affected by ocean acidification than hypercalcifying taxa. Although experimental evidence on physiological response is lacking, the secretion of radiolarian siliceous shells should be easier under slightly reduced $\mathrm{pH}$ than in more alkaline water. The apparent lack of a significant response of radiolarians to the acidification event at the Paleoence/Eocene boundary (Hollis 2006) supports this contention.

Thus if ocean acidification played a major role in the end-Triassic mass extinctions, we would expect strong extinctions among hypercalcifying and physiologically unbuffered organisms and low extinctions of radiolarians. The selectivity among calcifying taxa has already demonstrated to be in accordance with a scenario of ocean acidification (Kiessling \& Simpson 2010) and our results provide further support. One may ask why radiolarians responded so strongly to the endPermian mass extinction for which hypercapnia and ocean acidification have also been evoked (Knoll et al. 2007; Payne et al. 2007). We propose that $\mathrm{CO}_{2}$ release may have been devastating for calcifying organisms but shallow-water anoxia (Wignall \& Twitchett 1996) were perhaps the dominant trigger of radiolarian extinctions at that time.

\section{Conclusions}

Radiolarians did show considerable extinctions across the Triassic-Jurassic boundary. Extinction rates are merely reflecting Triassic to Early Jurassic background rates rather than representing a mass extinction. The often-observed difference between Triassic and postTriassic radiolarian faunas, may largely stem from this difference in background extinction rates. That radiolarians survived the end-Triassic environmental crisis relatively unscathed supports the contention that ocean acidification may have been an important proximate killing mechanism for taxa like corals, coralline sponges, and brachiopods, which invest strongly into the secretion of calcium-carbonate skeletons.

\section{Acknowledgements}

This work was funded by the VolkswagenStiftung. The University of Lille 1 is acknowledged for sponsoring a visiting professorship for WK, which made this paper possible. We thank Uta Merkel for entering many radiolarian occurrence data and Austin Hendy and Arnie Miller for contributing to the dataset. Three anonymous reviewers provided useful comments. This is Paleobiology Database Publication \#119.

\section{References}

Alroy, J., Marshall, C. R., Bambach, R. K., Bezusko, K., Foote, M., Fürsich, F. T., Hansen, T. A., Holland, S. M., Ivany, L. C., Jablonski, D., Jacobs, D. K., Jones, D. C., Kosnik, M. A., Lidgard, S., Low, S., Miller, A. I., Novack-Gottshall, P. M., Olszewski, T. D., Patzkowsky, M. E., Raup, D. M., Roy, K., Sepkoski, J. J., Jr., Sommers, M. G., Wagner, P. J. \& Webber, A. 2001. Effects of sampling standardization on estimates of Phanerozoic marine diversification. - Proceedings of the National Academy of Sciences (USA) 98: 6261-6266.

Beerling, D. 2002. $\mathrm{CO}_{2}$ and the end-Triassic mass extinction. - Nature 415: 386-387.

Carter, E. S. 1993. Biochronology and paleontology of uppermost Triassic (Rhaetian) radiolarians, Queen Charlotte Islands, British Columbia, Canada. - Mémoires de Géologie (Lausanne) 11: 1175 .

Carter, E. S. 1994. Evolutionary trends in latest Norian through Hettangian radiolarians from the Queen Charlotte Islands, British Columbia. - Geobios, Memoir Special 17: 111-119.

Carter, E. S. \& Hori, R. S. 2005. Global correlation of the radiolarian faunal change across the Triassic-Jurassic boundary. - Canadian Journal of Earth Sciences 42: 777-790.

Carter, E. S., Whalen, P. A. \& Guex, J. 1998. Biochronology and paleontology of Lower Jurassic (Hettangian and Sinemurian) radio- 
larians, Queen Charlotte Islands, British Columbia. - Geological Survey of Canada Bulletin 496: 1-162.

Cirilli, S., Marzoli, A., Tanner, L., Bertrand, H., Buratti, N., Jourdan, F., Bellieni, G., Kontak, D. \& Renne, P. R. 2009. Latest Triassic onset of the Central Atlantic Magmatic Province (CAMP) volcanism in the Fundy Basin (Nova Scotia): New stratigraphic constraints. - Earth and Planetary Science Letters 286: 514-525.

De Wever, P. 1981. Hagiastridae, Patulibracchiidae et Spongodiscidae (radiolaires polycystines) du Lias de Turquie. - Revue de Micropaléontologie 24: 27-50.

De Wever, P., Dumitrica, P., Caulet, J. P., Nigrini, C. \& Caridroit, M. 2001. Radiolarians in the sedimentary record. Gordon \& Breach Sc., London.

De Wever, P., O’Dogherty, L., Caridroit, M., Dumitrica, P., Guex, J., Nigrini, C. \& Caulet, J. P. 2003. Diversity of radiolarian families through time. - Bulletin de la Société géologique de France 174: 453-469.

De Wever, P., O’Dogherty, L. \& Gorican, S. 2006. The plankton turnover at the Permo-Triassic boundary, emphasis on radiolarians. Eclogae Geologicae Helvetiae 99: S49-S62.

Dromart, G., Garcia, J.-P., Picard, S., Atrops, F., Lécuyer, C. \& Sheppard, S. M. F. 2003. Ice age at the Middle-Late Jurassic transition? - Earth and Planetary Science Letters 213: 205-220.

Foote, M. 2000. Origination and extinction components of taxonomic diversity: general problems. - Paleobiology 26 (supplement): $74-$ 102 .

Foote, M. 2005. Pulsed origination and extinction in the marine realm. - Paleobiology 31: 6-20.

Galfetti, T., Bucher, H., Brayard, A., Hochuli, P. A., Weissert, H., Guodun, K., Atudorei, V. \& Guex, J. 2007. Late Early Triassic climate change: Insights from carbonate carbon isotopes, sedimentary evolution and ammonoid paleobiogeography. - Palaeogeography, Palaeoclimatology, Palaeoecology 243: 394-411.

Hautmann, M. 2004. Effect of end-Triassic $\mathrm{CO}_{2}$ maximum on carbonate sedimentation and marine mass extinction. - Facies 50 257-261.

Hautmann, M., Benton, M. J. \& Tomasovych, A. 2008. Catastrophic ocean acidification at the Triassic-Jurassic boundary. - Neues Jahrbuch für Geologie und Paläontologie Abhandlungen 249: $119-127$.

Hesselbo, S. P., Gröcke, D. R., Jenkyns, H. C., Bjerrum, C. J., Farrimond, P., Bell, H. S. M. \& Green, O. R. 2000. Massive dissociation of gas hydrate during a Jurassic oceanic anoxic event. - Nature 406: 392-395.

Hollis, C. 2006. Radiolarian faunal turnover through the PaleoceneEocene transition, Mead Stream, New Zealand. - Eclogae Geologicae Helvetiae 99: S79-S99.

Hori, R. S. 1992. Radiolarian biostratigraphy at the Triaissic/Jurassic period boundary in bedded cherts from the Inuyama area, central Japan. - Journal of Geosciences, Osaka City University 35: 5365.

Kiessling, W., Aberhan, M., Brenneis, B. \& Wagner, P. J. 2007. Extinction trajectories of benthic organisms across the Triassic-Jurassic boundary. - Palaeogeography, Palaeoclimatology, Palaeoecology 244: 201-222.

Kiessling, W. \& Simpson, C. 2010. On the potential for ocean acidification to be a general cause of ancient reef crises. - Global Change Biology doi: 10.1111/j.1365-2486.2010.02204.x.

Knoll, A. H., Bambach, R. K., Payne, J. L., Pruss, S. \& Fischer, W. W. 2007. Paleophysiology and end-Permian mass extinction. - Earth and Planetary Science Letters 256: 295-313.

Longridge, L. M., Carter, E. S., Smith, P. L. \& Tipper, H. W. 2007. Early Hettangian ammonites and radiolarians from the Queen Charlotte Islands, British Columbia and their bearing on the defi- nition of the Triassic-Jurassic boundary. - Palaeogeography, Palaeoclimatology, Palaeoecology 244: 142-169.

Marzoli, A., Bertrand, H., Knight, K. B., Cirilli, S., Buratti, N., Vérati, C., Nomade, S., Renne, P. R., Youbi, N., Martini, R., Allenbach, K., Neuwerth, R., Rapaille, C., Zaninetti, L. \& Bellieni, G. 2004. Synchrony of the Central Atlantic magmatic province and the Triassic-Jurassic boundary climatic and biotic crisis. - Geology 32: 973-976.

Marzoli, A., Renne, P. R., Piccirillo, E. M., Ernesto, M., Bellieni, G. \& Min, A. D. 1999. Extensive 200-million-year-old continental flood basalts of the Central Atlantic Magmatic Province. Science 284: 616-618.

McElwain, J. C., Beerling, D. J. \& Woodward, F. I. 1999. Fossil plants and global warming at the Triassic-Jurassic boundary. Science 285: 1386-1390.

O’Dogherty, L., Carter, E. S., Dumitrica, P., Gorican, S., De Wever, P., Hungerbühler, A., Bandini, A. N. \& Takemura, A. 2009a. Catalogue of Mesozoic radiolarian genera. Part 1: Triassic. - Geodiversitas 31: 231-270.

O'Dogherty, L., Carter, E. S., Dumitrica, P., Gorican, S., De Wever, P., Bandini, A. N., Baumgartner, P. O. \& Matsuoka, A. 2009b. Catalogue of Mesozoic radiolarian genera. Part 2: Jurassic-Cretaceous. - Geodiversitas 31: 271-356.

O'Dogherty, L., Carter, E. S., Dumitrica, P., Gorican, S. \& De Wever, P. 2009c. An illustrated and revised catalogue of Mesozoic radiolarian genera - objectives, concepts and guide for users. - Geodiversitas 31: 191-212.

O'Dogherty, L., Carter, E. S., Gorican, S. \& Dumitrica, P. 2010. Triassic radiolarian biostratigraphy. - Geological Society, London, Special Publications 334: 163-200.

Payne, J. L., Lehrmann, D. J., Follett, D., Seibel, M., Kump, L. R., Riccardi, A., Altiner, D., Sano, H. \& Wei, J. 2007. Erosional truncation of uppermost Permian shallow-marine carbonates and implications for Permian-Triassic boundary events. - Geological Society of America Bulletin 119: 771-784.

Preto, N., Kustatscher, E. \& Wignall, P. B. 2010. Triassic climates: State of the art and perspectives. - Palaeogeography, Palaeoclimatology, Palaeoecology 290: 1-10.

Racki, G. 1999. Silica-secreting biota and mass extinctions: survival patterns and processes. - Palaeogeography Palaeoclimatology Palaeoecology 154: 107-132.

Sepkoski, J. J., Jr. 2002. A compendium of fossil marine animal genera. - Bulletins of American Paleontology 363: 1-563.

Simms, M. J. \& Ruffell, A. H. 1989. Synchroneity of climatic change and extinctions in the late Triassic. - Geology 17: 265-268.

Takemura, A., Sakai, M., Sakamoto, S., Aono, R., Takemura, S. \& Yamakita, S. 2007. Earliest Triassic Radiolarians from the ARH and ARF sections on Arrow Rocks, Waipapa Terrane, Northland, New Zealand. - GNS Science Monograph 24: 97-107.

van de Schootbrugge, B., Quan, T. M., Lindstrom, S., Puttmann, W., Heunisch, C., Pross, J., Fiebig, J., Petschick, R., Rohling, H. G., Richoz, S., Rosenthal, Y. \& Falkowski, P. G. 2009. Floral changes across the Triassic/Jurassic boundary linked to flood basalt volcanism. - Nature Geoscience 2: 589-594.

Wignall, P. B. \& Benton, M. J. 1999. Lazarus taxa and fossil abundance at times of biotic crisis. - Journal of the Geological Society (London) 156: 453-456.

Wignall, P. B. \& Twitchett, R. J. 1996. Oceanic anoxia and the end Permian mass extinction. - Science 272: 1155-1158.

Yao, A. 1997. Faunal change of Early - Middle Jurassic radiolarians. News of Osaka Micropaleontologists, Special Volume 10: 155-182.

Yeh, K.-Y. \& Cheng, Y.-N. 1998. Radiolarians from the Lower Jurassic of the Busuanga Island, Philippines. - Bulletin of the National Museum of Natural Science (Taiwan) 11: 1-65. 